\title{
The Effect of Foreign Capital on Domestic Investment in Togo
}

\author{
Akilou Amadou \\ Faculté des Sciences Economiques et de Gestion \\ Université de Lomé, B.P. 1515, Togo \\ Tel : (228)-991-33 61/336 7369 E-mail : akilouamadou@yahoo.fr \\ Accepted: May 4, 2011 \\ doi:10.5539/ijef.v3n5p223
}

Received: April 20, 2011

\begin{abstract}
Theoretically, openness to foreign capital can stimulate domestic investment in developing countries' or harm their economies by raising the risks of financial crises. It's why in this paper, we have analyzed the impact of foreign capital on domestic investment in Togo over the period 1970-2008. The results we have obtained by using error correction models indicate that overall foreign capital affects positively and significantly domestic investment. It also appears that foreign direct investment (FDI) and loans are the main channels through which foreign capital has a positive impact on domestic investment in Togo. The impact of portfolio investment is negative, but not significant.
\end{abstract}

Keywords: Foreign capital, Domestic investment, FDI, Loans, Portfolio investment, Togo

Classification JEL : C22, F21, F34

\section{Introduction:}

In Togo, domestic resources are relatively insufficient to finance investments in economic and social sectors. Thus, economic growth rates remain so weak to allow a remarkable reduction of poverty. For instance, domestic savings rate decreased considerably since the end of $70 \mathrm{~s}$, going from $39.8 \%$ of the gross domestic product (GDP) in 1978 to only $4.9 \%$ in 2005 . Theoretically, the access to international financial markets can thus be very beneficial for the country. Indeed, the inflows of foreign capital can result in a reduction of interest rates or increase the volume of credit available to finance investments. Foreign capital can also have an indirect effect on domestic investment through what Kose et al. (2006) call the "collateral benefits", because in order to attract foreign investors, developing countries' governments are forced to set up place good macroeconomic policies, improve political and economic governance. Loans and portfolio investments also contribute to the deepening and the expansion of financial markets. Moreover, even if they are not directly intended for capital formation, foreign loans can be used to increase or smooth consumption. This can thus stimulate the growth of GDP during the periods of decrease in the demand. In addition, foreign direct investment (FDI) can make favor the transfer of new technologies and good practices in management, and consequently involves an improvement of productivity.

However, opening the domestic financial markets to international transactions may increase the risks of financial crises or cause risks which are not observed in domestic markets, particularly foreign exchange rates risks. FDI also can "oust" domestic investment if multinational firms (FMN) raise the level of productivity and oblige their local competitors to leave some markets. Moreover, FDI related to merger and acquisitions do not contribute directly to capital formation, unless new foreign owners do not modernize or do not increase their acquisitions by investing in new technologies.

So it is difficult to determine at first sight the impact of foreign capital inflows on domestic investment. This is why the main purpose of this paper is to analyze the impact of foreign capital on domestic investment in Togo. The emphasis will be put essentially on the direct effect of foreign capital on domestic investment.

Section 2 is devoted to literature review, while sections 3 and 4 are respectively devoted to methodology and analysis of empirical results. Section 5 is related to conclusion.

\section{Literature review}

Many economists advocate free capital movement because it enables to seek the highest rate of return. The movements of capital without restrictions can also result in several other advantages (Feldstein, 2000). Firstly, international capital flows reduce the risks which the owners of capital face by allowing them to diversify their loans and investments. Secondly, global integration of financial markets can contribute to the spreading of better practices such as good management of enterprises and good rules of accountancy. Thirdly, the international mobility of capital can limit the capacity of governments to carry out bad policies. According to Mody and Murshid (2005), governments often control movements of capital in order to direct them towards specific investment projects. For 
instance, in many countries, FDI is directed towards mining and sovereign loans are intended for the reduction of bottlenecks in the field of infrastructures. The controls of capital movements are also meant to keep domestic savings at home. However, since capital control increases the costs of transaction, "capital flight" is relatively limited. Thus, the control of capital can enhance the link between foreign capital and domestic investment, either by the direct orientation of foreign loans towards specific investment projects or by discouraging the outflows of capital In addition, in the presence of capital control, the central banks may feel less threatened by the possibility of sudden market variations and choose to maintain few reserves, thus increasing inflows of capital for investment.

When an economy opens itself to private capital movements, the impact on investment depends on the environment of domestic investment and the objectives of investors. Two different situations can be considered. Firstly, if the marginal returns on capital are higher than international interest rate, substantial capital will enter this economy and will compensate domestic saving, thus leading to a strong relation between foreign capital and domestic investment. Blanchard and Giavazzi (2002), for example, found that the openness of Greece and Portugal, within the framework of their adhesion to European monetary union, lead to significant entries of capital which is used to finance investment and consumption. A second case arises when an economy opens to foreign capital when domestic returns are low, or not higher than international market interest rates. According to Kraay and Ventura (1999), foreign capital can still enter this economy for diversification purposes. However, foreign capital inflows may not amplify domestic investment. Developing economies seem to belong to this category because the lack of infrastructures reduces the returns of capital.

It is also important to distinguish between the different types of foreign capital. Because of their specialization, foreign direct investors have an advantage compared to portfolio and domestic investors. According to Mody et al. (2003), this advantage enables them to surpass the other types of investors for the most productive opportunities and leads to more investment than those undertaken by domestic investors or foreign investors in portfolio in the same context. This effect is strong when domestic productivity is high, because foreign direct investors will then be able to increase much more the effect of their specialized knowledge. However, the net effect of FDI on domestic investment will depend on the decisions of domestic investors. If the returns of residual investment opportunities are weak, domestic saving can be directed out of a country to search for higher returns or to reduce risks.

Bosworth and Collins (1999) carried out a study on the effect of foreign capital on domestic investment in 58 developing countries over the period 1978-95. They distinguished three different types of capital, namely FDI, portfolio investment, and other financial flows - mainly bank credits. They found that an increase of one dollar in capital inflows result in an increase in domestic investment approximately of 50 cents. This outcome hides however significant differences between the various types of capital. FDI seems to cause an increase of investment by one for one. On the other hand, portfolio investment practically does not have a perceptible effect on domestic investment. The impact of loans is between the two first. The relatively high coefficient of FDI, compared with those of portfolio investment and foreign loans, suggests that FDI contributes more appreciably to the productivity of domestic capital than other types of foreign capital. Mileva (2008) found results similar to those of Bosworth and Collins with a sample of transitional economies. The coefficients obtained by Mody and Murshid are respectively 0.72 for FDI, 0.61 for foreign loans and 0.46 for portfolio investment. Mody and Murshid also divided their data into two sub-periods and noted that the impact of FDI inflows and loans decreased in the 90s comparatively to the 80 s, even though developing countries reduced the restrictions on their capital accounts.

A distinctive feature of FDI analyzed by Razin and Sadka (2003) is connected with the control and management of firms. In a large company which has many relatively small shareholders, each shareholder faces a problem of "free riding". If a shareholder does something to improve the quality of investment, then all other shareholders will enjoy the benefits. Thus, some shareholders will under-invest in monitoring the management actions. But if a company belongs to a restricted number of investors, the problem of "free riding" will be lessened, and in some cases can disappear. Consequently, the quality of investment improves, and the average volume of investments increases. The prospects of domestic economy's productivity growth tend to reinforce the intensity of FDI flows, but they also provide a positive incentive for an increase in the domestic investment expenditures. Thus, the growth of productivity jointly stimulates FDI flows and domestic investment.

\section{Methodology and data}

The general form of the model that is used to estimate the effect of foreign capital on domestic investment in Togo is:

$$
I_{t}=\alpha K_{t}+\beta X_{t}+\varepsilon_{t}
$$

Where $I$ represents domestic investment, $K$ refers to foreign capital and $X$, a vector of control variables. $\varepsilon$ and $t$ are respectively the term of error and time. 
The selected control variables are the rate of economic growth, the uncertainty related to this growth rate and the cyclical variation of the money and quasi money (M2) in \% of GDP. These variables have been chosen because of their potential role in the determination of domestic investment. Indeed, the rate of economic growth is an indicator of the effect of demand on investment (the principle of acceleration). Because of irreversibility, uncertainty is also important in the decision of investment. Any unanticipated drop in demand could, for example, affect the rate of return of investment. However, theoretically, the relation between investment and uncertainty remains unspecified. The cyclic variation of M2/GDP is an indicator of liquidity available to finance investment.

The data used are annual and collected from the databases of World Bank (Africa Development Indicators, CD-ROM 2008-09). The covered period is 1970 to 2008. Domestic investment is measured by the Gross domestic investment in \% of GDP. Economic growth rate is measured by the growth rate of real GDP per capita. Uncertainty is measured by the conditional variance obtained by GARCH method suggested by Serven $(1998,2003)$. The cyclic variation of M2/GDP is measured by the variation of M2/GDP relative to its 3 years moving average. Foreign capital is at first measured by overall net foreign capital (model 1). Then, it has been broken down into FDI, loans, and portfolio investment in order to identify its components that affect the most domestic investment in Togo (model 2).

\section{Analysis of empirical results}

Data used being time series, unit root and co-integration tests are initially carried out in order to determine the most suitable estimation method of our model. Augmented Dickey-Fuller (ADF) tests are used to carry out unit root tests. The results obtained indicate that all the variables are stationary in first differences at $5 \%$ (see table 1).

As all the variables are stationary in first differences, the two stages method of Engle and Granger is used for the test of co-integration. This method consists initially in the estimation of long run relations. The residues obtained are then subjected to the unit root test to see whether they are stationary or not. The results are recapitulated in table 2 . According to the results shown in table 2, the values of ADF statistics are higher than critical values. So the variables of the two models are co-integrated. That is why error correction models (ECM) have been estimated.

The results obtained are summarized in table 3. The coefficients of the one period lagged residue are negative and significant at 5\%. So ECM explains well the effect of foreign capital on domestic investment in Togo. In addition, all the coefficients have the excepted signs and except for the growth rate of real GDP and portfolio investment all of them are significant at $5 \%$.

Overall foreign capital affects domestic investment positively (table 3, model 1). For instance, an increase in foreign capital of a unit involves an increase in domestic investment rate of 0.613 .

It also appears that FDI and loans are the most important channels through which foreign capital affects positively and significantly domestic investment in Togo (table 3, model 2). An increase in FDI of a unit involves that of domestic investment of 1.116; whereas an increase in loans of the same amount involves that of domestic investment of 0.911 . This can be explained by the direct and induced effects of FDI. On the other hand, portfolio investments affect negatively, but not significantly domestic investment in Togo.

\section{Conclusion}

In developing countries, such as Togo, where domestic financial resources are relatively insufficient, foreign capital can be used as a lever for domestic investment. It's why in this paper, we analyzed the impact of foreign assets on domestic investment in Togo by using error correction models. The results we obtained from 1970 to 2008 indicate that overall foreign capital affects positively and significantly domestic investment. Furthermore, it appears that FDI and loans are the components through which foreign capital has a positive impact on domestic investment. On the other hand, the effect of portfolio investment is negative, but not significant. Togo could thus increase the level of its domestic investment by encouraging foreign capital inflows, in particular FDI and loans.

\section{References}

Blanchard, O. and F. Giavazzi. (2002). Current account deficits in the euro area: the end of the Feldstein-Horioka puzzle?, Brookings Papers on Economic Activity 2, 147-210. doi:10.1353/eca.2003.0001, http://dx.doi.org/10.1353/eca.2003.0001

Bosworth, B. and S. M. Collins. (1999). Capital flows to developing economies: implications for saving and investment, Brookings Papers on Economic Activity 1, 143-169. doi:10.2307/2534664, http://dx.doi.org/10.2307/2534664

Feldstein, M. (2000). Aspects of Global Economic Integration: Outlook for the Future, NBER Working Paper No. 7899.

Mileva, E. (2008). The impact of capital flows on domestic investment in transition economies, European Central Bank Working Paper Series 871. 
Mody, A. and A. P. Murshid. (2005). Growing up with capital flows, Journal of International Economics 65, 249-266. doi:10.1016/j.jinteco.2004.02.003, http://dx.doi.org/10.1016/j.jinteco.2004.02.003

Kose, M. A., E. Prasad, K. Rogoff, and S.-J. Wei. (2006). Financial Globalization: A Reappraisal, IMF Working Paper 06/179.

Kraay, A. and J. Ventura. (1999). Current accounts in debtor and creditor countries, The Quarterly Journal of Economics 115, 1137-1166. doi:10.1162/003355300555033, http://dx.doi.org/10.1162/003355300555033

Mody, A., A. Razin and E. Sadka. (2003). The role of information in driving FDI flows: host-country transparency and source country specialization, IMF Working Paper No. 03/148.

Razin, A. and E. Sadka. (2003), Gains from FDI inflows with incomplete information, Economics Letters 78(1), 71-77. doi:10.1016/S0165-1765(02)00179-9, http://dx.doi.org/10.1016/S0165-1765(02)00179-9

Servén, L. (1998). Macroeconomic uncertainty and private investment in developing countries: an empirical investigation, World Bank Policy Research Working Paper 2035.

Servén Luis. (2003). Real-Exchange Rate Uncertainty and Private Investment in LDCS, The Review of Economics and Statistics 85(1), 212-218.

Table 1. Results of unit root tests on variables in first differences

\begin{tabular}{|l|c|c|}
\hline Variables & Critical values (at 5\%)* & ADF Statistic * \\
\hline Domestic investment/GDP & 5.79 & 2.95 \\
\hline Real GDP growth rate & 10.76 & 2.95 \\
\hline Uncertainty & 6.73 & 2.95 \\
\hline Cyclical variation of M2/GDP & 8.50 & 2.95 \\
\hline Overall foreign capital & 4.11 & 2.95 \\
\hline FDI & 5.30 & 2.95 \\
\hline Loans & 3.59 & 2.95 \\
\hline Portfolio investment & 9.75 & 2.95 \\
\hline
\end{tabular}

* : in absolute values

Table 2. Results of the unit root tests on the residues of long run relation

\begin{tabular}{|l|c|c|}
\hline & ADF Statistic* & Critical values at 5\%* \\
\hline Model 1 & 4.40 & 2.95 \\
\hline Model 2 & 4.04 & 2.95 \\
\hline
\end{tabular}

* : in absolute values

Table 3.Estimations results

Dependent variable: domestic investment /GDP)

\begin{tabular}{|l|c|c|}
\hline Explanatory variables (in first differences) & Model 1 & Model 2 \\
\hline Real GDP growth rate & 0.124 & 0.057 \\
\hline Cyclical variation of M2/GDP & $1.080^{* *}$ & $1.076^{* *}$ \\
\hline Uncertainty & $0.388^{* *}$ & $0.415^{* *}$ \\
\hline Overall foreign capital & $0.613^{* *}$ & - \\
\hline \multicolumn{1}{|c|}{ FDI } & - & $1.116^{* *}$ \\
\hline Loans & - & $0.911^{* *}$ \\
\hline Portfolio Investment & - & -0.536 \\
\hline Constant (C) & -0.144 & -0.236 \\
\hline One period lagged residue & $-\mathbf{0 . 7 1 2 * *}$ & $\mathbf{- 0 . 4 9 5 * *}$ \\
\hline $\mathrm{R}^{2}$ & 0.8085 & 0.7631 \\
Adjusted R & 0.7765 & 0.6993 \\
Durbin-Watson statistic & 2.08 & 2.00 \\
F statistic & 25.32 & 11.96 \\
Prob. of F statistic & 0.000 & 0.000 \\
\hline
\end{tabular}

** : significance at $5 \%$ 